\title{
NIH report vindicates Gallo on conduct of AIDS research
}

Washington. The US National Institutes of Health's (NIH) two-year investigation of alleged misconduct by two of its own scientists - AIDS researchers Robert C. Gallo and Mikulas Popovic - has now come close to the end with completion of a report by the NIH Office of Scientific Integrity (OSI) that, as with so many OSI reports that are distributed to principals and Congress, has leaked to the press.

The impetus for the OSI investigation was an article published in the Chicago Tribune by John Crewdson in November 1989 , in which Crewdson implied that Gallo may have stolen the AIDS virus from French colleagues. Directly or by innunendo, the Tribune article also challenged the validity of some of Gallo's published work and criticized his behaviour generally in the race to identify the cause of AIDS.

The OSI report, written in January, clears Gallo of charges of misconduct but is nonetheless critical of the way he runs his laboratory at the National Cancer Institute. The report finds Popovic guilty of three instances of misconduct in writing the paper in which the Gallo laboratory reported successful growth of an AIDS virus isolate and it concludes that Gallo "breached his overall responsibility...as senior author to ensure the accuracy of the paper." While the OSI says it cannot "condone" Gallo's behaviour it also said the alleged breach of responsibility does "not constitute scientific misconduct."

The report is sternly critical of Gallo in many places and acknowledges that its authors did not always agree with one another on how to evaluate the evidence before them. Thus, the actual findings of the report and its language are sometimes at odds.

The OSI finds now, as it did a year ago, no evidence to support allegations that Gallo stole or otherwise misappropriated the virus he used in the development of the AIDS blood test from his former colleague, Luc Montagnier of the Pasteur Institute in Paris.

The OSI, in its 114-page typed report, exonerates Gallo of misconduct in more than 15 counts of alleged data misrepresentation in a paper published in the 4 May 1984 issue of Science on which Popovic was principal author. In addition, the report notes that three other Gallo papers in the same issue (each with a different principal author) accurately report the experimental data - a point that contributed to the OSI's decision to put the blame for shortcomings in the first paper squarely on Popovic (see story below).

Further, OSI takes issue with Crewdson's interpretation of several events, generally taking the position that the evidence does not support a negative conclusion.

Defining scientific misconduct as "falsification, fabrication or plagiarism", the OSI has exonerated Gallo of virtually all charges against him. The report notes that one dissenter believed that a broader definition of misconduct should apply. According to the report, one unnamed OSI investigator believed that Gallo's oversight of his laboratory and attention to detail in the Popovic paper showed an "apparent disregard...for accuracy and responsibility in the conduct and reporting of research [that it] did constitute scientific misconduct."
This is the second version of the OSI report, the first having been rejected several months ago by NIH director Bernadine Healy more for its style than its content. She praises the new version for laying out the allegations and the evidence on both sides, as well as for putting the OSI analysis in clear focus. In substance, she says, the new version is similar to the first draft.

Representative John Dingell (Democrat, Michigan), who has the earlier draft, has already declared the revised report "watered down."

An additional report figures in the NIH's final disposition of the Gallo case. In an effort to ensure that the OSI's investigation was both comprehensive and did not favour $\mathrm{NIH}$, former acting director William Raub created an ad hoc committee of advisers to act as a board of overseers. Never formally constituted as a government committee, the group was assembled under the chairmanship of Yale University crystallographer Frederic Richards.

Following transmission of OSI's final report to Healy in January, the so-called Richards committee submitted its own view of the case. Although the language of the OSI's report suggests in places that its exoneration of Gallo was somewhat grudging, the Richards committee was overtly critical of his conduct.

The committee accused Gallo of "intellectual recklessness", blamed him for inadequately describing the extent of his laboratory's study of the French virus and suggested that, by allegedly failing to share the (continued on page 4)

\section{OSI finds Popovic guilty on Science paper}

Mikulas Popovic, the Czech-born chemist (now unemployed) who performed the crucial experiments in Robert Gallo's laboratory that resulted in the growth of an AIDS virus in sufficient quantity to develop a blood test, is guilty of three instances of misconduct. The OSI report focuses on the paper he published in the 4 May 1984 issue of Science describing his work.

- Two tables in the paper includes the notation "ND", stated as meaning not done. However, analysis of laboratory notebooks showed that in each instance an immunofluorescence analysis of the "ND" cells had in fact been done. The OSI did not accept Popovic's rebuttal that he meant "'not determinable' because the findings did not make sense when compared to the other data..." in In reporting immunofluoresence assay results, Popovic wrote 10 per cent in a table, whereas the notebook kept by his technician reads "very few cells positive for rabbit antibody". OSI termed his data falsification, rejecting Popovic's claim that the 10 per cent figure was derived from his independent visual analysis of the cells.
- One of the more unusual aspects of Popovic's experiment was a decision to pool several HIV isolates into a viral soup in an effort to get one of them to grow vigorously. A sentence in the Science paper says that the cultures used in the pool were "first" shown to have reverse transcriptase (RT) activity (indicating the presence of a retrovirus) is "false". Only one of ten samples was shown to be RT positive before being pooled.

According to OSI, the word "first" appeared in the seventh draft of the manuscript. Not until the eighth draft did it appear as a separate sentence. Popovic denies writing the sentence, although it is not clear who, among many editorial hands, did. However, OSI concludes that because Popovic bears overall responsibility for the paper, he is responsible for the error and, therefore, guilty of scientific misconduct.

In passing the OSI's report up the line, NIH director Bernadine Healy has recommended leniency, noting that the cited errors are not "material" to the validity of the paper whose findings have stood the test of time.

B.J.C. 
(continued from page 3 )

AIDS virus with colleagues once he and Popovic had successfully grown it in permanent cell lines, Gallo actually slowed the pace of AIDS research. Further, the committee faulted the OSI for its focus on the one Science paper in its final analysis of the case, arguing that by so doing it missed the forest for the trees in terms of assessing Gallo's professional behaviour.

The two reports put Healy in a quandary. If the Richards committee's view was fair, then the OSI's exoneration on strict definitional grounds might be misplaced, she reasoned, before doing what people in Washington do. Healy created a committee to advise her on the reports of the OSI and Richards committees: she convened the scientific directors of the $13 \mathrm{NIH}$ institutes and gave them both reports.

Then, going one step further, Healy called Gallo before her own committee of advisers for three hours on the night of 23 March and challenged him, in effect, to rebut the allegations of the Richards committee. According to Healy and others who participated in the interrogation, Gallo did just that. In the words of one participant, "He blew the directors away, including those prejudiced against him."

Whether that is an exaggeration or not, participants agree that Gallo presented compelling evidence in his defence. For instance, on the serious charge of failure to share HIV with other laboratories, he presented files showing that the virus was sent to some 45 laboratories around the world in the months following the May 1984 paper in Science. (However, it is true that, because of a petty argument, Gallo was slow to give samples of HIV to his NIH colleague, Malcolm Martin, who subsequently suggested that the structural similarity between the Montagnier and Gallo isolates argued that Gallo's isolate HTLV-III was really the French virus in disguise.)

The Richards committee did not examine (nor, apparently, ask for) evidence to support its conclusions, relying instead on the OSI. Thus, it did not know the extent to which HIV had been distributed. At Healy's request, four members of the committee did meet with Gallo recently for 30 minutes but it was not a fact-finding occasion.

Taking the evidence altogether, Healy came down on Gallo's side in her letter of transmittal of the report to HHS authorities. Gallo, she says, has been absolved and, unless those higher up in HHS who have final responsibility for approving the report fail to approve it, the department should do everything it can to "restore Dr. Gallo's reputation." This is not to say that Gallo deserves any prizes for collegiality in science. But "if collegiality is the measure by which we evaluate good scientists", she says, "we might as well shut down right now".

One particularly thorny issue of collegiality centres on Gallo's role in editing a paper by Montagnier that was pub-

\title{
The OSI on Crewdson on Gallo
}

\author{
The OSI is frank in admitting that much of its investigation was driven by an article \\ published in the Chicago Tribune by John Crewdson in November 1989. Although \\ Crewdson's article presented no new facts, the way he wove together known \\ information implied a pattern of behaviour that could add up to misconduct. The two \\ examples given here are illustrative of the OSI's analysis of the Crewdson opus. \\ Throughout the AIDS dispute, the extent of Gallo's study of LAV, and his \\ acknowledgment of that extent, has been an issue. In 1986, through a Freedom of \\ Information Act filing, US attorneys for the French received a copy of a letter written in \\ 1983 about electron microscopy of several HIV samples from Gallo's lab. The original \\ letter included EM positive data suggesting that LAV was growing in two cell lines. \\ In the copy of that letter, as received by the French lawyers and subsequently read \\ by Crewdson, all reference to LAV was deleted. According to the OSI report, "The 1989 \\ Chicago Tribune article did not assert Dr. Gallo or one of his colleagues was \\ responsible for the deletion, but there was an implication that this might be the case." \\ In fact, an investigation revealed that Gallo's copy of the letter did contain a \\ reference to LAV and that the altered version had come from somewhere else. (Gallo \\ has always seen this as evidence someone conspired against him.) Although the \\ source has never been found, OSI concluded that Crewdson's "implication" could not \\ be sustained by the evidence. \\ - Crewdson hinted at misconduct on Gallo's part because data in conference \\ proceedings from a presentation at a 1983 meeting in Cold Spring Harbor included \\ information that had not actually been presented. "The implication of the Chicago \\ Tribune article was that the Gallo et al. chapter [published in 1984 with updated \\ information] ... overstated the [Gallo lab's] progress toward discovering the cause of \\ AIDS. The inquiry team did not find convincing evidence for this assertion." In fact. \\ most of the chapters were updated, including one by "Luc Montagnier et al." B.J.C.
}

lished along with papers by Gallo in the 20 May 1983 issue of Science. The manuscript, which Montagnier sent to the magazine via Gallo, lacked an abstract which Gallo offered to write. In addition, he suggested two editorial changes in the paper that have generated endless dispute.

The OSI's analysis of this episode is illustrative of the tone of the report. A sentence added to the paper said, "The DNA sequence of these and other members of the HTLV (human T-cell leukemia virus) family being compared." OSI concludes that the added sentence is "in line with the substance" of the initial version of the paper, but it goes on to say that "The mere fact of the addition....without the explicit, unequivocal agreement of the coauthors... [constitutes] a gratuitous, self-serving, and improper act on the part of Dr. Gallo."

The OSI report, however, does not stop there. In reaching its final analysis, it notes that because Montagnier received galleys of his manuscript, and could have objected to the added sentence if he wished, the editing by Gallo does not amount to scientific misconduct.

In an angry rebuttal to this (and other points), Gallo's attorney, Joseph Onek, argues that because it was Gallo who reviewed the manuscript favourably for Science and agreed to hold publication of his own paper until Montagnier's was ready, it is unfair to attack him. "Is this uncollegial?" he asks.

And so it goes.

The "final" OSI report is, sad to say, not the end of this tiresome story. Once the report is cleared by her political bosses at HHS, Healy will argue for its open publication. Gallo's attorney, who along with Popovic's lawyer has written a rebuttal challenging points in the OSI report that impugn Gallo's behaviour, has said that if the report is made public, his rebuttal should accompany it. There will be plenty for Gallo supporters to like, in particular, the conclusion of "not guilty", and plenty for Gallo's critics to cite against him.

Meanwhile, Healy, angered by the unceasing accusations against Gallo, is arguing for an open administrative hearing to review the case yet again. She suggests bringing in an independent administrative law judge to run it. Referring to a recent nationally televised broadcast in which antiGallo parties to the dispute accused him of stealing or otherwise "misappropriating" the French virus, Healy says that "these people should come forward at an administrative hearing and present their evidence. On television they can say what they like. If they have evidence, I want to hear it."

Meanwhile, a dispute over distribution of royalties from the US AIDS blood test remains to be resolved. The French are asking for a greater share of the money in light of data uncovered this year that the virus both Montagnier and Gallo thought had come from a French patient known as BRU actually was contaminated, first in France and then in the United States, by a virus from another French patient known as LAI. But that's another story.

Barbara J. Culliton 